\title{
GEOTECHNICAL ASPECTS OF RAILWAY TUNNEL CONSTRUCTION NEAR RUDOLTICE
}

Construction of the tunnel in Třbovice v Čechách has been, from the geotechnical aspect, the most problematic issue ever, and, we would like to define some of the reasons and to sketch a potential solution.

\section{Introduction}

The article presents a project of railway tunnel from the point of view of potential short term or long term geotechnical risks; it means risks in the course realisation and operation time. There had been elaborated many variant projects for the new tunnel on main railroad between the cities Krasíkov and Česká Třebová in the Czech Republic in the leg Třebovice v Čechách - Rudoltice v Čechách. We would like to present some positive and negative aspects of one project variant presented by the company Metropro- jekt, and, another one is "Study of Project Modification" presented by consortium Krasíkov.

\section{Engineering-geological and Hydro-geological Conditions}

Geological structure of the area where the railway line was traced is a typically complicated structure of lateral formation. There are quarternary fluvial and deluvial deposits of average thickness

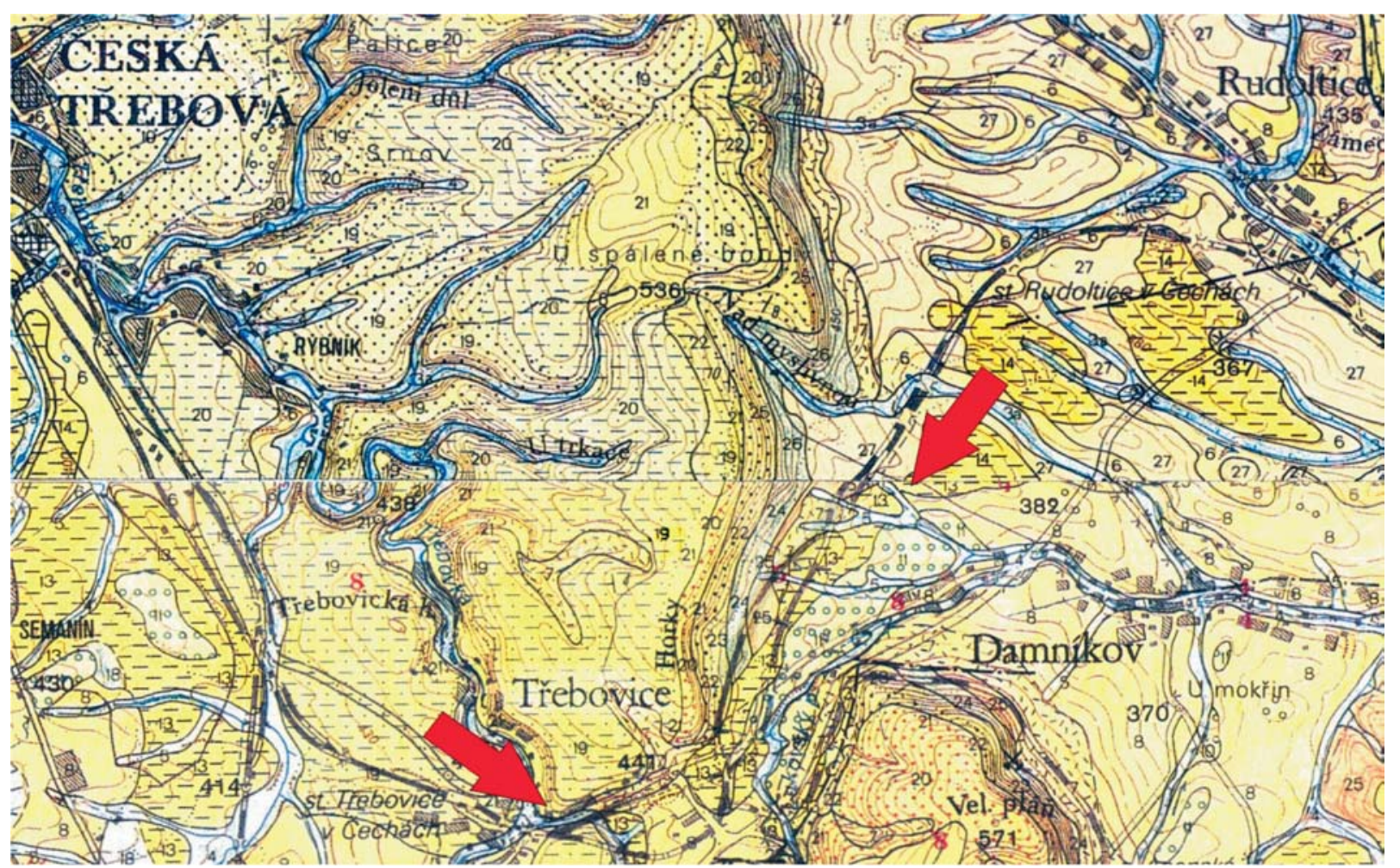

Fig. 1 General Geological Map of Area Near Rudoltice

\footnotetext{
* ${ }^{1}$ Marián Drusa, ${ }^{2}$ Vladimír Gróf

${ }^{1}$ Department of Geotechnics, Faculty of Civil Engineering, University of Žilina, Komenského 52, 01026 Žilina, Slovak Republic.

Tel: +421-41-7634818, Fax +421-41-7233502, E-mail: drusa@fstav.utc.sk

${ }^{2}$ GeoExperts Ltd. Žilina, Bytčická 82, 01001 Žilina, Slovak Republic. Tel: +421-41-5006915, Fax: +421-41-5006915,

E-mail: vladimir_grof@geoexperts.sk
} 
of 6 up $8 \mathrm{~m}$ on Miocene's clays of significant thickness, which are occasionally calcareous, with thin closed layers of gravel and organic mixtures. General geological area map of the new tunnel projects is shown on Fig.1. Stronger rock environment of Mesozoic origin lies deeper. The described geological environment of Miocene's clays may be evaluated from the point of view its suitability for underground structures as an unacceptable for construction of new tunnel. Surroundings of the future tunnel excavation can be classified as very squeezed and unstable in changed conditions caused by tunnelling.

From the engineering-geological aspect the "Study of Project Modification" is more advantageous in comparison with the "Metroprojekt Tunnel Design", as there is only a little trenching of Miocene's unstable clayey layer.

Both presented variants of railway track leading of shaft sinking tunnel will infringe hydro-geological conditions in close geological environment. Deeper excavation into a rock mass on a considerably longer section should be great disadvantage of the first variant. A substantial part of the first variant new railway tunnel is situated in line of the old tunnel, which is draining surrounding rock environment, but, because of its smaller dimensions, it is less influential. In the presented geological environment, the water flows more through quarternary permeable soil layers than impermeable Miocene's clays. There should be taken into consideration the hydraulics impacts to the surrounding territory after being built-up a large scale barrier element, represented by the excavated tunnel.

\section{Geotechnical Risks of Tunnel Construction}

The scope of the second variant, presented by consortium "Krasíkov", is to reduce the tunnel length in order to minimize the impact to unsuitable layer of Miocene's clays. There are real fears from this geological formation, which have originated in construction difficulties of previous "Třebovice Tunnel" as well as from many foreign negative experiences with construction of tunnel in squeezing and swelling rock environment. It has been generally known that the tunnel construction in swell and squeezed rock materials is the most difficult task as an underground construction.

Based upon the existing state of tunnelling know-how the objective geological space might be classified into one of the groups:

- swell rock environment with a swelling based upon physical and chemical reaction with water and not upon a mechanical principle. There are very well known problems with osmotic swelling of clayey minerals group of smectites or clayey mixture-layered minerals. Further relevant swelling environments are anhydrite formations. These formations may produce high pressure on bottom tunnel vault;

- hardly squeezed rock formation occur mainly in faulty zones in the case of the tunnel excavation, where then acts all-round high rock stress on the tunnel lining;
- swell-squeeze rock environment, where swelling is of a mechanical character, i.e., in its deconsolidation, respectively, in plastic stress strain deformation of rock.

As it may be seen, the term "swelling" may be attributed to two various mechanisms of rock volume increase. As there has not been found any information concerning the presence of smectite minerals in the layer of Miocene's clay, it might be presumed that no chemical swelling mechanism in the course of construction "Třebovice tunnel" would occur. The authors Klepsatel, Kusý, (2003) state that possible reason of the swelling process in the old "Třebovice tunnel" had been haeving of organic matters, present in geological formation in substantial amount

The precise composition of these substances is not known, thus, it is very important to understand the swelling mechanism for being able to forecast potential geotechnical risks, especially in a long-term horizon. If speaking about a short-term one - the construction will be in any case very demanding. From the long-term point of view, we are not able to evaluate exactly all geotechnical risks at the current state of information. When speaking only about mechanical swelling, with an adequate project of the tunnel, the first version would not bring any higher risk than the other one in the long-term horizon. It is presumed that on the basis of present knowledge of potential behaviour of Miocene's clay, it would be better to trace the railway tunnel line in accordance with the second version. Tracing the railway line above the layer of

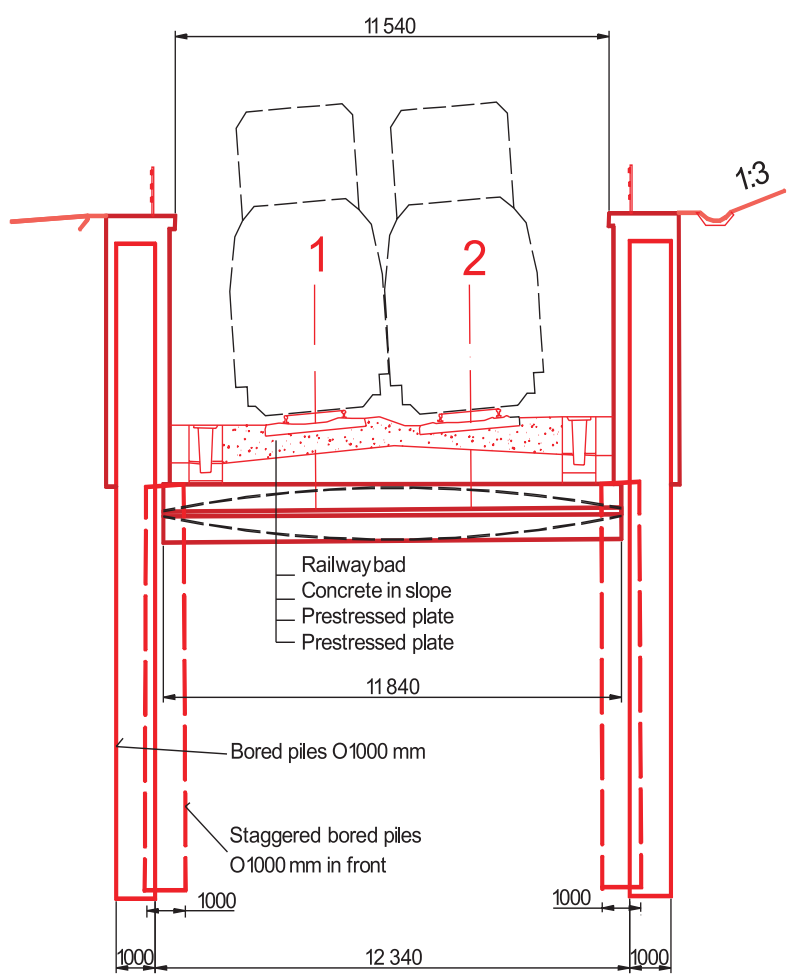

Fig. 2 Cross Section of Railroad 
Miocene's clays and, also the designed geotechnical constructions, are technically correct.

The follow-up calculation of pile retaining wall and its external stability against sliding has been done; the calculation evaluated also the depth of fixation of double-row piled wall. Precise dimensioning and calculation of the other parts of construction should be solved in a final realization project. The basic idea of the projected second version presented by the consortium "Krasíkov" is shown in cross-section in Fig. 2.

\section{Interference of New and Current Structures}

The first version of the tunnel project will have to solve the crossing of the railway-line across a recultivated waste dump, analysis of the embankment stability and speeding-up consolidation will be next tasks. At this line section reinforcing and hardening of subsoil must be solved by appropriate geo-technology or the layer of anthropogenous artificial soils will be excavated to an adequate depth. The following technical task of project will be a stability analysis of the high embankment and evaluation of consolidation time of the embankment on soft soils. The project must involve also a calculation of consolidation velocity, according to a realization project, and, a designed distance of sand drains or geodrains (PSK, Alimac, Membradrain ...) or, there may be used trenching lime, cement or rock columns that would improve subsoil deformations properties, too. The second version should solve strengthening of rock environment around the tunnel excavation at the crossing of a new railway line over the old tunnel (inclined micropiles or use the appropriate manner) and the next back-filling of the old tunnel and build-up the drainage canal.

\section{Geotechnical and Environmental Aspects}

When considering the geotechnical point of view, the locality for construction of the tunnel must be taken as a very problematic, especially because of the existence of very thick Miocene's clays strata. Undoubtedly, a more convenient solution, when taking into consideration technical and economical aspects, would be the version of the consortium "Krasikov" that avoids trenching of the Miocene's layer, as mentioned above, because of the stability problems of cuts and plastic bulging of embankments after construction of the tunnel.

When comparing the presented versions, the latter one has a substantially less negative impact on the hydro-geological conditions in the locality, as well as on the surrounding fauna and flora.

\section{Comparison of Versions}

Positives and negatives of the first version "Metroprojekt Tunnel Design" may be summarized in the following Table 1 .
Tab. 1

\begin{tabular}{|c|c|}
\hline Pros & Cons \\
\hline $\begin{array}{l}+ \text { very safe technology of tunnel } \\
\text { construction in closed chambers } \\
\text { with elimination of deformation } \\
\text { zones of monolithic "Milan" } \\
\text { walls }\end{array}$ & $\begin{array}{l}\text { - presumption of unfavourable } \\
\text { and unexpected geotechnical } \\
\text { problems } \\
\text { - depth of foundation of new } \\
\text { structure and its impact on } \\
\text { surroundings } \\
\text { - hard excavation in layer of } \\
\text { Miocene's clays } \\
\text { - negative influence on } \\
\text { underground water on long } \\
\text { distance section of territory, } \\
\text { where is railway traced } \\
\text { - tracing of railway-line by high } \\
\text { embankments on soft subsoil } \\
\text { - expected three-dimensional } \\
\text { deformations in tunnel } \\
\text { surroundings } \\
\text { - longer railway tunnel and } \\
\text { retaining walls } \\
\text { - more constable maintenance } \\
\text { - construction time and its risks } \\
\text { - demanding construction } \\
\text { technology }\end{array}$ \\
\hline
\end{tabular}

Positives and negatives of "Study of Project Modification" presented by the consortium Krasíkov are shown in Table 2.

Tab. 2

\begin{tabular}{|c|c|}
\hline Pros & Cons \\
\hline $\begin{array}{l}\text { + reduction construction time } \\
+ \text { lover costs of geotechnical } \\
\text { construction } \\
+ \text { shorter tunnel length and } \\
\text { retaining walls length } \\
+ \text { less hydro-geological impact on } \\
\text { tunnel environment } \\
+ \text { simple construction technology } \\
\text { comparing with the first version } \\
+ \text { lower costs for ground } \\
\text { excavation above the } \\
\text { Miocene's clayey layer and safer } \\
\text { technology } \\
+ \text { reduced length of the track line } \\
+ \text { future cost effective maintenance } \\
\text { of tunnel and retaining walls }\end{array}$ & $\begin{array}{l}\text { - higher inclination of the track } \\
\text { line } \\
\text { - higher deformation zones } \\
\text { around piled walls } \\
\text { - crossing new track line over the- } \\
\text { existing tunnel }\end{array}$ \\
\hline
\end{tabular}

Having considered all the impacts and factors that could infringe the construction of the tunnel, we would like to recommend the tracing in the sense of the second version, submitted by the consortium "Krasíkov". 


\section{References}

[1] KLEPSATEL, KUSÝ, MAŘÍK: Construction of Tunnel in Rock Mass, Jaga Bratislava, 2003

[2] MÍČA, L., HUBÍK, P., MYNÁŘ, J., MINÁ̌̃, L.: Railway Corridors Construction Using Rigid Geogrid Reinforcement in the Czech Republic, In. Proc. Second European Geosynthetics Conference, Bologna, Italy, pp. 403-409, 2000

[3] SLIVOVSKÝ, DRUSA, GRÓF, AMMAN, BUCHER: Geotechnical Evaluation of Pliocene's Clays in subsoil of Railway-line Zlaté Moravce Lužianky, Geotechnika Bratislava, 1997 